\title{
ERRATUM
}

Marta Blanca Mazzetti · María Cristina Taira

Sandra Marcela Lelli · Eduardo Dascal

Juan Carlos Basabe

Leonor Carmen San Martín de Viale

\section{Hexachlorobenzene impairs glucose metabolism in a rat model of porphyria cutanea tarda: a mechanistic approach}

Published online: 21 November 2003

(C) Springer-Verlag 2003

\section{Kurztitel (2003) DOI 10.1007/s00204-003-0470-y}

In the following sentence in the "Discussion," "derepression" was incorrectly replaced in proof by "depression." The sentence should read as follows:
"Since glucose represses ALA-S (Tschudy et al. 1964), low glucose would lead to derepression of this enzyme, a fact that contributes to the induction of this regulatory enzyme promoted by HCB (Wainstok de Calmanovici et al. 1984)."

The online version of the original article can be found at http:// dx.doi.org/10.1007/s00204-003-0470-y

M. B. Mazzetti $\cdot$ M. C. Taira · S. M. Lelli

L. C. S. M. de Viale $(\square)$

Departamento de Química Biológica,

Facultad de Ciencias Exactas y Naturales,

Universidad de Buenos Aires, Ciudad Universitaria,

C1428BGA Ciudad Autónoma Buenos Aires,

Argentina

E-mail: smartin@qb.fcen.uba.ar

Tel.: + 54-11-45763342

Fax: + 54-11-45763342

E. Dascal · J. C. Basabe

Centro de Investigaciones Endocrinológicas (CEDIE).

Hospital de Niños, Dr. Ricardo Gutierrez,

C1425EDF, Ciudad Autónoma Buenos Aires,

Argentina

Present address: L. C. S. M. de Viale

O'Higgins 4332, CP 1429, Buenos Aires, Argentina 